\title{
The Employment of Cognitive and Metacognitive Strategies in Bilingual Pupils' Creative Writing
}

\author{
Athina Geladari and Konstantinos Mastrothanasis \\ University of Western Macedonia \\ athinageladari@yahoo.gr,kostas_0231@yahoo.gr
}

\begin{abstract}
The present research investigates the employment of cognitive and metacognitive strategies by bilingual pupils and the processes followed when they compose a short story in Greek (L2). The sample was comprised by 43 pupils enrolling in the 5 th and 6 th grade of Primary School. Data was collected through think-aloud protocols and individual retrospective interviews. The findings revealed variations between the two levels of language proficiency (good-weak writers) and types of bilingualism (simultaneous-successive) in terms of employing effective strategies and flexibility in strategy choice. Pupils' difficulties were focused in the selection of appropriate vocabulary and organization of ideas.
\end{abstract}

\section{Introduction}

Writing is a complex, recursive cognitive process involving mental processes and strategy use. As highlighted in the theoretical frameworks of L2 writing, a host of factors affect writing performance, such as syntax, lexicon, task objectives and "socio-cultural" factors (Lantolf 2004). Various writing processes are propounded in the best known models of L1 or L2 composing (Silva \& Brice 2004). These models assume that various processes are responsible for textconstruction activity. The mental processes of writing encompasses a series of stages (basically pre-writing, writing, reviewing, and rewriting) involving multiple drafts.

It has been underlined that among the factors that affect the process and product of $\mathrm{L} 2$ writing (a learner's language proficiency, metacognitive knowledge about the writing task, employment of writing strategies, writers' personal characteristics), writing strategies are particularly remarkable since it is their use

(cc) BY-NC-ND 
that primarily separates successful from less successful writers (Baroudy 2008; Victori 1999).

Strategies can pave the way toward greater proficiency, learner autonomy, and self-regulation (Hsiao \& Oxford, 2002). There are various classifications of writing strategies and processes which were termed with different labels and have been used to interpret bilinguals writing processes and actions (Wenden 1991; Riazi 1997; Sasaki 2000). According to the classification of O'Malley and Chamot (1990), metacognitive strategies are those actions that aim at monitoring the writing process consciously without the direct involvement of the target language. Cognitive strategies are those writers use to implement actual writing actions and require a straightforward involvement with the target language (Carson \& Longhini 2002). Cognitive strategies help students comprehend and produce language and include summarizing, translating, and taking notes while metacognitive strategies direct the acquisition of knowledge through self-monitoring, evaluating, or identifying the purpose of a language task (Olivares-Cuhat 2002).

Studies investigating part of or the entire process of L2 writing commonly have reached to the conclusions that unskilled $L 2$ writers tend to plan less and revise more at the word and phrase level (De Larios et al. 2006; Baroudy 2008), are less concerned about surface level revisions and more committed to the given assignment (Sasaki 2002). Diversly, skilled L2 writers plan more, revise at the discourse level, and elaborate in order to do the task most effectively (De Larios et al. 2006; Sasaki 2002). Strategy use is also influenced by the language proficiency, gender, school year or learning styles (Chamot 2004; Green \& Oxford 1995; Lee 2003; Ehrman et al. 2003).

Studies indicate that the unsuccessful writers tend to use rote memorization, repetition of spelling words, but seldom apply cognitive strategies in lesson review (Olivares-Cuhat 2002; Sasaki 2002). Skilled writers have a complete repertoire of strategies for planning, generating, organizing, and revising text (Griva et al. 2009). As for the relationship of strategy use and proficiency level, many studies had similar results that highproficiency students used strategy use more frequently than those in the lower proficiency levels (Green \& Oxford 1995; Khali 2005; Lan \& Oxford 2003; Lee 2003; Oxford 1990).

Much less is the literature focusing on differences between the strategies employed by simultaneous and successive bilinguals. Although, some recent studies provide evidence that simultaneous bilinguals, who have learned both languages at the same time, show different strategies and speeds in the development of writing skills (Akita et al. 2007), engage in planning, spell more correctly in both languages in spite of different orthographies (Berman 1994). Successive bilinguals, who usually learn the second language in a different age and different context, after the 
establishment of their first language, are less flexible in lexical choice and spelling (Sousa et al. 2011).

Thus, the study takes into account of the writers' cognitive and metacognitive strategies by efficient and less efficient bilingual pupils and different types of bilingualism, simultaneous and successive. Knowing what skilled writers do as they compose, what specific strategies they use when they write, will help students to become better writers (Nyikos \& Oxford 1993). Planning, revising, and managing the writing process are the "know-how" they need to become strategic writers (Harris \& Graham 1994). There have been lots of studies investigating the strategy use (Green \& Oxford 1995) suggesting that strategies are culturerelated and culture-specific (Olivares-Cuhat 2002; Bazerman 2008) and if they are used appropriately, they can be the crucial factors related to success in language learning especially for the inexperienced students (Ehrman et al. 2003).

\section{The study}

The present research can be considered as an attempt to provide a source of insight into the strategies employed by bilingual children while writing in Greek.

The reason of the study stemmed from the observed constant immigration influxes in Greece and the increasing immigrant pupils who are enrolling Greek primary school classes. Their differentiated linguistic and cultural backgrounds comprise of a teaching and educational challenge. The study aims at identifying the writing strategies and recording the difficulties observed during creative writing as well as tracing possible correlations between the language proficiency level and type of bilingualism.

More specifically, the study investigates the following questions:

a) What are the strategies that bilingual pupils use in the pre-, while- and post- writing stage of their creative writing?

b) Are the employed cognitive and metacognitive strategies used efficiently?

c) What are the difficulties confronted by the pupils?

d) Do pupils of the two language proficiency levels and types of bilingualism differ in their strategy employment and confronted difficulties?

\subsection{Sample}

43 Albanian pupils ( 23 boys and 20 girls) who attended the $5^{\text {th }}$ and $6^{\text {th }}$ grade ( $M$ $=11,27 \pm 0.31$ years old) took part in the study. They were selected from a larger number of bilingual pupils, according to their language proficiency and type of bilingualism. 


\subsection{Procedure}

All bilingual pupils were distributed the screening standardized test for the detection and investigation of their deficiencies and difficulties in the process of writing (Porpodas, et al., 2007). The pupils were grouped into two writing competence levels, according to their scores at the aforementioned test: the weak writers and the good writers.

Think-aloud protocols, semi-structured interviews and key-observations were chosen for the identification of the cognitive and metacognitive strategies that were employed during the writing process key-observations.

Each participant was asked to write a short narrative story based on five key words they were given. At the same time, they were asked to express their thoughts while planning, organizing ideas, writing and reviewing, focusing on the difficulties encountered. The individual semi-structured retrospective interviews followed next to allow flexible data collection so that emergent issues could be explored in depth, along with the discussion of the key themes regarding the writing strategies used and the overlapping of the difficulties that occurred in writing. Pupils' behaviors were recorded, using a key-observation created by the researchers for the reasons of this research and had been piloted on previous stage.

\subsection{Data Analysis}

The Statistical Package for the Social Sciences (SPSS) was used for the quantitative data analysis. The techniques of Chi-square test $\left(\chi^{2}\right)$, Monte Carlo test and Cramer's $V$ test were performed in order to identify differences in strategy use between more and less competent readers as well as the types of bilingualism. The Cramer's V correlation is mentioned as the most statisticallysound method for determining relationships.

The consistency of the ratings assigned by the two raters (the researchers) and the inter-rater reliability of the classification of data was examined. Interrater reliability in classifying the data in variables should be both substantive and statistically significant. In this light, we employed sequentially four reliability indexes: Scott's Pi (p), Cohen's kappa (Ck), Krippendorff's alpha (a), and Fleiss' kappa (Fk), each of which provided a high score of reliability and significance (.82).

The verbal data, after being analyzed qualitatively, resulted in groups of categories/sub-categories, (Miles \& Humberman, 1994), which were classified into basic thematic strands. The analysis of qualitative data resulted in thirtyseven (37) codes that were subsumed in eight (8) categories: cognitive prewriting strategies, metacognitive pre-writing strategies, cognitive while-writing strategies, metacognitive while-writing strategies, cognitive post-writing strategies, metacognitive post-writing strategies, word level writing difficulties 
and text level writing difficulties. The categories were grouped into four basic thematic strands: a) pre-writing strategies, b) while-writing strategies, c) postwriting strategies, and d) writing difficulties. Afterwards, contrastive tables were formed for each pupil, that were next commented. In order to evaluate writers' strategy efficiency, each strategy was rated from 0 to 2, depending on their inefficient (0), relatively efficient (1) or efficient use (2). Similarly, the referred and detected difficulties were also assessed from 0 to 2: 0 for low difficulty, 1 for fair difficulties 2 for high difficulty.

\section{Results}

\subsection{Cognitive and Metacognitive Writing Strategies}

The qualitative analysis of verbal data (think aloud protocols and semi-structured interviews) resulted in 37 codes considering bilingual pupils' employment of cognitive and metacognitive strategies while writing creatively. 16 of the codes correspond to the use of cognitive strategies (see Table 1 ) while the rest 14 are connected with the adoption of metacognitive strategies by the pupils (see Table 2).

The strategies of resourcing ideas (47 reports), retrieving from background knowledge (35 reports), local (33 reports) and global rereading (31 reports), retrieving ( 25 reports) and generating ideas ( 24 reports) were the most employed cognitive strategies in all three stages of the writing process.

Evaluating local production (32 reports), global planning (31 reports), error correction on the post-writing stage (29 reports) as well as on while-writing stage (26 reports), monitoring local production (27 reports) and planning (26 reports) were the strategies most preferred in all stages.

\subsubsection{Pre-writing Stage}

A large number of pupils employed certain cognitive and metacognitive writing strategies on the pre-writing phase, in order to plan and make drafts. The most employed strategies were: resourcing ideas (47 reports), generating ideas (24 reports), retrieving background knowledge (35 reports) and hypothesizing (14 reports). Pupils comment on their actions before writing: "when I realized what I had to do I started thinking how I will be relevant with it. I would like it to be like a fairy tale and I think I did it right" (pupil 6).

The metacognitive strategies of this stage were connected to global planning (31 reports), evaluating of ideas (23 reports) and rehearsing (18 reports). A pupil mentioned: "I was thinking too long to decide what I could write. I wanted to pick 
Table 1.

Codes related to cognitive writing strategies

\begin{tabular}{|l|l|l|l|}
\hline Codes & Interpretation & Stage & Occurrences \\
\hline RESIDE & Resourcing ideas & Pre-writing & 47 \\
\hline RETRIP & Retrieving & Pre-writing & 35 \\
\hline LORERD & Local rereading & Writing & 33 \\
\hline REREAD & Rereading & Post-writing & 31 \\
\hline RETRIW & Retrieving & While-writing & 25 \\
\hline GENIDE & Generating ideas & Pre-writing & 24 \\
\hline AVOIDA & Avoidance & While-writing & 23 \\
\hline ELABOR & Elaborating & While-writing & 21 \\
\hline TRANSL & Translating & While-writing & 19 \\
\hline MAKCON & Making connections & While-writing & 18 \\
\hline TRANSC & Transcribing & Post-writing & 17 \\
\hline LOCREV & Local revising & While-writing & 16 \\
\hline REVISIN & Revising & Post-writing & 16 \\
\hline HYPOTH & Hypothesizing & Pre-writing & 14 \\
\hline RESIDS & Researching ideas & While-writing & 12 \\
\hline RECALL & Recalling & While-writing & 9 \\
\hline & & & \\
\hline
\end{tabular}

Table 2.

Codes related to metacognitive writing strategies

\begin{tabular}{|l|l|l|l|}
\hline Codes & Interpretation & Stage & Occurrences \\
\hline EVALPR & Evaluating local production & While-writing & 32 \\
\hline GLOPLA & Global planning & Pre-writing & 31 \\
\hline ERRCOR & Error correction & Post-writing & 29 \\
\hline MONLPR & Monitoring local production & While-writing & 27 \\
\hline PLANN & Planning & While-writing & 26 \\
\hline ERCORW & Error correction & While-writing & 26 \\
\hline EVALID & Evaluate ideas & Pre-writing & 23 \\
\hline MONPRO & Monitoring Production & Post-writing & 23 \\
\hline REHIDE & Rehearsing ideas & Pre-writing & 18 \\
\hline EVAPRO & Evaluating Production & Post-writing & 16 \\
\hline REHSTR & Rehearsing structure & While-writing & 15 \\
\hline EVAABI & Evaluating ability & Post-writing & 12 \\
\hline EVPATA & Evaluating paragraph task & While-writing & 8 \\
\hline FEEDBA & Feedback & While-writing & 7 \\
\hline
\end{tabular}


interesting ideas. If an idea wasn't appealing enough, I would think of something better. When I had planned every part of the story, I tried to organize the ideas and then I started writing" (pupil 32).

The quantitative analysis of the pre-writing strategies (see Table 3 ) indicates that almost all cognitive and metacognitive strategies are used relatively efficiently.

Table 3.

Descriptive indices for pre-writing strategies employment.

\begin{tabular}{|l|l|c|c|c|}
\hline Categories & Codes & Inefficient use & Relatively efficient use & Efficient use \\
\hline \multirow{4}{*}{$\begin{array}{l}\text { Cognitive } \\
\text { Strategies }\end{array}$} & RESIDE & $20,9 \%$ & $41,9 \%$ & $37,2 \%$ \\
\cline { 2 - 5 } & RETRIP & $23,3 \%$ & $44,2 \%$ & $32,6 \%$ \\
\cline { 2 - 5 } & GENIDE & $30,2 \%$ & $25,6 \%$ & $44,2 \%$ \\
\cline { 2 - 5 } & HYPOTH & $37,2 \%$ & $27,9 \%$ & $34,9 \%$ \\
\hline \multirow{3}{*}{$\begin{array}{l}\text { Metacognitive } \\
\text { strategies }\end{array}$} & GLOPLA & $34,9 \%$ & $39,5 \%$ & $25,6 \%$ \\
\cline { 2 - 5 } & EVALID & $34,9 \%$ & $39,5 \%$ & $25,6 \%$ \\
\cline { 2 - 5 } & REHIDE & $37,2 \%$ & $37,2 \%$ & $25,6 \%$ \\
\hline
\end{tabular}

However, some differentiations were observed regarding the levels of writers. The good writers used all cognitive and metacognitive pre-writing strategies more effectively than the weak, who were less engaged to the prewriting processes. The $\chi^{2}$ and the Monte Carlo independence tests indicated some statistically significant differentiations between the two levels of writing competence. Similarly, the Cramer's $V$ test strengths the relationship between the writing level and the effective use of pre-writing cognitive and metacognitive strategies (see Table 4).

Table 4.

Differences between good and weak writers in cognitive and metacognitive strategies use

\begin{tabular}{|c|c|c|}
\hline Categories & Codes & Weak-Good Writers \\
\hline \multirow{4}{*}{ Cognitive Strategies } & RESIDE & $\begin{array}{l}\chi^{2}=15,457, d f=2, p=0,000 \\
\text { Cramer's V }=0,600\end{array}$ \\
\hline & RETRIP & $\begin{array}{l}\chi^{2}=25,306, d f=2, p=0,000 \\
\text { Cramer's V }=0,767\end{array}$ \\
\hline & GENIDE & $\begin{array}{l}\chi^{2}=21,974, d f=2, p=0,000 \\
\text { Cramer's V }=0,715\end{array}$ \\
\hline & HYPOTH & $\begin{array}{l}\chi^{2}=27,592, d f=2, p=0,000 \\
\text { Cramer's V }=0,801\end{array}$ \\
\hline \multirow{3}{*}{$\begin{array}{l}\text { Metacognitive } \\
\text { strategies }\end{array}$} & GLOPLA & $\begin{array}{l}\chi^{2}=15,719, \mathrm{df}=2, \mathrm{p}=0,000 \\
\text { Cramer's V }=0,605\end{array}$ \\
\hline & EVALID & $\begin{array}{l}\chi^{2}=23,824, d f=2, p=0,000 \\
\text { Cramer's V }=0,744\end{array}$ \\
\hline & REHIDE & $\begin{array}{l}\chi^{2}=25,604, d f=2, p=0,000 \\
\text { Cramer's V }=0,772\end{array}$ \\
\hline
\end{tabular}


Moreover, no statistical differentiations were detected for the types of bilingualism.

\subsubsection{While-writing Stage}

On the most creative stage, the while-writing, a major number of both cognitive and metacognitive strategies were used efficiently so that pupils achieve their goals. Particularly, almost all pupils adopted local rereading (33 reports) efficiently or relatively efficiently level $(97,6 \%)$ unlike other cognitive strategies. Pupils reread locally either to detect and correct their mistakes, or to revise (16 reports) their compositions, or finally, to come up with further related ideas (12 reports) (see Table 5). A pupil mentioned on local rereading: "I read everything I have written in these two sentences to check whether I have missed a spelling mistake because I wasn't careful enough about the spelling" (pupil 18).

Table 5.

Descriptive indices for while-writing strategies employment

\begin{tabular}{|c|c|c|c|c|}
\hline Categories & Codes & Inefficient use & Relatively efficient use & Efficient use \\
\hline \multirow{9}{*}{$\begin{array}{l}\text { Cognitive } \\
\text { Strategies }\end{array}$} & LORERD & $2,3 \%$ & $20,9 \%$ & $76,7 \%$ \\
\hline & RETRIW & $4,7 \%$ & $27,9 \%$ & $67,4 \%$ \\
\hline & AVOIDA & $14,0 \%$ & $37,2 \%$ & $48,8 \%$ \\
\hline & ELABOR & $23,3 \%$ & $30,2 \%$ & $46,5 \%$ \\
\hline & TRANSL & $25,6 \%$ & $53,5 \%$ & $20,9 \%$ \\
\hline & MAKCON & $34,9 \%$ & $41,9 \%$ & $23,3 \%$ \\
\hline & LOCREV & $34,9 \%$ & $30,2 \%$ & $34,9 \%$ \\
\hline & RESIDS & $16,3 \%$ & $34,9 \%$ & $48,8 \%$ \\
\hline & RECALL & $20,9 \%$ & $53,5 \%$ & $25,6 \%$ \\
\hline \multirow{7}{*}{$\begin{array}{l}\text { Metacognitive } \\
\text { strategies }\end{array}$} & EVALPR & $34,9 \%$ & $44,2 \%$ & $20,9 \%$ \\
\hline & MONLPR & $32,6 \%$ & $32,6 \%$ & $34,9 \%$ \\
\hline & PLANN & $30,2 \%$ & $37,2 \%$ & $32,6 \%$ \\
\hline & ERCORW & $32,6 \%$ & $37,2 \%$ & $30,2 \%$ \\
\hline & REHSTR & $44,2 \%$ & $39,5 \%$ & $16,3 \%$ \\
\hline & EVPATA & $41,9 \%$ & $34,9 \%$ & $23,3 \%$ \\
\hline & FEEDBA & $34,9 \%$ & $41,9 \%$ & $23,3 \%$ \\
\hline
\end{tabular}

Other cognitive strategies that were employed by the participant bilingual writers were those of retrieval ( 25 reports), avoidance ( 23 reports) and elaborating (21 reports). It is noted that the pupils were trying to retrieve ideas in this stage, too, 
from their background knowledge, in order to enrich the content of their story ("...I thought what I will add! Last week I watched a cartoon on tv and I will use some parts of it in my story!"'), however avoiding perplexed plots and elaborated vocabulary. As marked by a pupil "I thought of something funny but I don't know how to describe it in Greek, so I'll skip it" (pupil 22). In some cases pupils recalled (9 reports) in order to constrain from making mistakes or to improve their thoughts. One of the participants said: "...when I have trouble expressing something I'm thinking about, I choose to write something else. I prefer using words I already am aware of, than searching them or trying to recall, despite the fact that my story will be less exciting" (pupil 7).

There were 21 reports on the strategy of elaborating while writing, when pupils' goal was to extend their writing as much as possible. A pupil commented on that: "I want my stories to be long and rich of information, because our teacher told us to write the more we can" (pupil 2). A large majority of the pupils tried to use connecting words and linkages (18 reports) so that their stories be coherent: "I want the reader to make sense of my text, so when I compose I am concentrated on using temporal connections and be specific. Many pupils don't do so and you can't really say what they've written about' (pupil 40).

Another also efficiently employed cognitive strategy proved to be translating (19 reports). The pupils who mentioned it claimed that they translated into Greek all the ideas they generated: "When I have to write something, I think about the topic firstly in Albanian and then I am saying it in Greek and, lastly, I write it down" (pupil 41).

Considering metacognitive strategies, a large part of the pupils were positive in evaluating (32 reports) and monitoring local production (27 reports), while many were those who were referred to the strategy of planning (26 reports). As mentioned: "I am thinking what I am going to say with these words. When I write I am careful to write it correctly so that it makes sense. When I finish it, I read it again so as to be ascertained that I've said everything I had thought" (pupil 15).

The metacognitive strategies of rehearsing the text structure (15 reports) and evaluating each paragraph (8 reports), were not employed effectively since, according to quantitative data, the $44,2 \%$ and $41,9 \%$ accordingly, make ineffective use of them, in reference to the goal of writing.

Another strategy that was employed on the while-writing stage is error correction (26 reports). Error correction seems to occur while pupils write ("When I realize that I have written something wrong I correct it immediately") or when pupils review their writings at the end, to spot mistakes and correct them ("When I have completed a whole paragraph I read it again to find any mistakes. I don't want anybody to think that I am a bad student and don't know how to write a story"). Concurrently, some pupils mentioned seeking for feedback (7 reports) as a metacognitive strategy that aids them improve their writing. As remarked "...l do my best. I want to be a good writer and I try hard for this. I think that the more I study and practice, the better writer I become". 
Some considerable statistical differentiations were discovered through chisquare $\chi^{2}$ and Monte Carlo independence tests for the pupils of different writing levels and types of bilingualism. Accordingly, the Cramer's $V$ test indicated significant correlation between the variables of competence level and type of bilingualism with the effective use of writing strategies (see table 6).

Table 6.

Differences between good-weak writers and successive-simultaneous bilinguals in cognitive and metacognitive strategies use

\begin{tabular}{|c|c|c|c|}
\hline Categories & Codes & Weak-Good Writers & $\begin{array}{l}\text { Successive-Simultaneous } \\
\text { Bilinguals }\end{array}$ \\
\hline \multirow{7}{*}{$\begin{array}{l}\text { Cognitive } \\
\text { Strategies }\end{array}$} & ELABOR & $\begin{array}{l}\chi^{2}=15,062, d f=2, p=0,001 \\
\text { Cramer's V=0,592 }\end{array}$ & \\
\hline & TRANSL & $\begin{array}{l}\chi^{2}=7,330, d f=2, p=0,026 \\
\text { Cramer's V=0,413 }\end{array}$ & $\begin{array}{l}\chi^{2}=9,649, d f=2, p=0,008 \\
\text { Cramer's } V=0,474\end{array}$ \\
\hline & \multirow{2}{*}{ MAKCON } & $\chi^{2}=12,539, d f=2, p=0,002$ & $\chi^{2}=11,042, d f=2, p=0,004$ \\
\hline & & Cramer's V $=0,540$ & Cramer's V=0,507 \\
\hline & LOCREV & $\begin{array}{l}\chi^{2}=16,196, d f=2, p=0,000 \\
\text { Cramer's V=0,614 }\end{array}$ & \\
\hline & RESIDS & $\begin{array}{l}\chi^{2}=6,485, d f=2, p=0,039 \\
\text { Cramer's V=0,039 }\end{array}$ & \\
\hline & RECALL & $\begin{array}{l}\chi^{2}=7,604, \mathrm{df}=2, \mathrm{p}=0,022 \\
\text { Cramer's V=0,421 }\end{array}$ & $\begin{array}{l}\chi^{2}=7,465, d f=2, p=0,024 \\
\text { Cramer's V }=0,417\end{array}$ \\
\hline \multirow{7}{*}{$\begin{array}{l}\text { Metacognitive } \\
\text { strategies }\end{array}$} & EVALPR & $\begin{array}{l}\chi^{2}=14,437, d f=2, p=0,001 \\
\text { Cramer's V=0,579 }\end{array}$ & \\
\hline & MONLPR & $\begin{array}{l}\chi^{2}=6,504, d f=2, p=0,039 \\
\text { Cramer's V }=0,389\end{array}$ & \\
\hline & PLANN & $\begin{array}{l}\chi^{2}=10,785, d f=2, p=0,005 \\
\text { Cramer's V=0,501 }\end{array}$ & \\
\hline & ERCORW & $\begin{array}{l}\chi^{2}=23,547, \mathrm{df}=2, \mathrm{p}=0,000 \\
\text { Cramer's V=0,740 }\end{array}$ & $\begin{array}{l}\chi^{2}=6,661, d f=2, p=0,036 \\
\text { Cramer's V=0,417 }\end{array}$ \\
\hline & REHSTR & $\begin{array}{l}\chi^{2}=21,713, \mathrm{df}=2, \mathrm{p}=0,000 \\
\text { Cramer's V=0,711 }\end{array}$ & \\
\hline & EVPATA & $\begin{array}{l}\chi^{2}=25,880, d f=2, p=0,000 \\
\text { Cramer's V=0,776 }\end{array}$ & \\
\hline & FEEDBA & $\begin{array}{l}\chi^{2}=11,650, d f=2, p=0,003 \\
\text { Cramer's V=0,521 }\end{array}$ & \\
\hline
\end{tabular}

\subsubsection{Post-writing Stage}

In the post-writing stage, a mediocre number of the bilingual students employed the strategies of rereading the whole text composition (17 reports), transcribing (16 reports) as well as revising (reports) all text. As pupils mentioned, they usually read the text they had composed ("I read what I've written to check it..."), to confirm the correctness and cohesion of their written production (monitoring production) (23 reports), to restore spelling and syntax mistakes (29 reports) ("I check the writing again at the end and I look-up some words to correct every 
mistake I spot" - pupil 19), evaluate the total production (16 reports) and their skills in writing (12 reports).

The quantitative analysis for the data that stemmed from this stage indicated that bilinguals tended to handle the cognitive strategies more effectively than the metacognitive ones (see Table 7). In particular, the cognitive strategies of rereading and transcribing are employed efficiently by the $41,9 \%$ and $51,2 \%$ accordingly. On the contrary, all metacognitive strategies seemed to be employed inefficiently on the post-writing stage.

Table 7.

Descriptive indices for post-writing strategies employment.

\begin{tabular}{|l|l|l|l|l|}
\hline Categories & Codes & Inefficient use & Partially efficient use & Efficient use \\
\hline \multirow{4}{*}{$\begin{array}{l}\text { Cognitive } \\
\text { strategies }\end{array}$} & REREAD & $23,3 \%$ & $34,9 \%$ & $41,9 \%$ \\
\cline { 2 - 5 } & TRANSC & $20,9 \%$ & $27,9 \%$ & $51,2 \%$ \\
\cline { 2 - 5 } & REVISIN & $32,6 \%$ & $39,5 \%$ & $27,9 \%$ \\
\hline \multirow{4}{*}{$\begin{array}{l}\text { Metacognitive } \\
\text { strategies }\end{array}$} & ERRCOR & $39,5 \%$ & $32,6 \%$ & $27,9 \%$ \\
\cline { 2 - 5 } & MONPRO & $32,6 \%$ & $37,2 \%$ & $30,2 \%$ \\
\cline { 2 - 5 } & EVAPRO & $37,2 \%$ & $34,9 \%$ & $27,9 \%$ \\
\cline { 2 - 5 } & EVAABI & $44,2 \%$ & $27,9 \%$ & $27,9 \%$ \\
\hline
\end{tabular}

The $\chi^{2}$ and Monte Carlo independence tests along with Cramer's V test highlighted significant differentiations concerning the effective strategy use of post-writing strategies by the two writing competence groups, as shown at Table 8 .

Table 8.

Differences between good-weak writers in cognitive and metacognitive strategies use

\begin{tabular}{|l|l|l|}
\hline \multirow{4}{*}{ Categories } & Codes & Weak-Good Writers \\
\hline \multirow{4}{*}{ Cognitive strategies } & REREAD & $\begin{array}{l}\chi^{2}=13,606, d f=2, p=0,001 \\
\text { Cramer's } V=0,563\end{array}$ \\
\cline { 2 - 3 } & TRANSC & $\begin{array}{l}\chi^{2}=11,892, d f=2, p=0,003 \\
\text { Cramer's V }=0,526\end{array}$ \\
\cline { 2 - 3 } & REVISIN & $\begin{array}{l}\chi^{2}=9,946, d f=2, p=0,007 \\
\text { Cramer's } V=0,481\end{array}$ \\
\hline \multirow{3}{*}{ Metacognitive strategies } & ERRCOR & $\begin{array}{l}\chi^{2}=17,894, d f=2, p=0,000 \\
\text { Cramer's } V=0,645\end{array}$ \\
\cline { 2 - 3 } & MONPRO & $\begin{array}{l}\chi^{2}=23,525, d f=2, p=0,000 \\
\text { Cramer's } V=0,740\end{array}$ \\
\cline { 2 - 3 } & EVAPRO & $\begin{array}{l}\chi^{2}=18,837, d f=2, p=0,000 \\
\text { Cramer's } V=0,662\end{array}$ \\
\cline { 2 - 3 } & EVAABI & $\begin{array}{l}\chi^{2}=20,883, d f=2, p=0,000 \\
\text { Cramer's } V=0,697\end{array}$ \\
\hline
\end{tabular}


Concerning the strategies employment by the two types of bilinguals, successive and simultaneous, no statistical differentiations were found.

\subsection{Difficulties in Writing}

Regarding the difficulties encountered by bilinguals at a lexical level, it seems that the use of appropriate vocabulary (27 reports) and spelling (27 reports) constitute the most frequently confronted hurdles (see table 9). As many of the participants mentioned: "I can't spell every word" (pupil 33), and "sometimes I am at short of words, I can't recall the word I want to use" (pupil 2).

Table 9.

Categories and codes regarding writing difficulties

\begin{tabular}{|l|l|l|l|}
\hline Categories & Codes & Interpretation & Occurrences \\
\hline \multirow{3}{*}{ Word level } & USAPVOC & Use of appropriate vocabulary & 27 \\
\cline { 2 - 4 } & CORSP & Correct spelling & 27 \\
\hline \multirow{4}{*}{ Text level } & GENID & Generating Ideas & 31 \\
\cline { 2 - 4 } & ORGID & Organizing Ideas & 32 \\
\cline { 2 - 4 } & CONPLA & Content planning & 36 \\
\cline { 2 - 4 } & SYNTX & Syntax & 14 \\
\cline { 2 - 4 } & CORGRAMM & Correct grammar & 23 \\
\hline
\end{tabular}

The general difficulties that were recorded focused on the production (31 reports) and organization of ideas (32 reports) and planning the content while thinking about the topic (36 reports). Some pupils mentioned that syntax represents also an obstacle for the completion of a successful short story (14 reports). The correct use of the grammatical rules of the Greek language (23 reports) is also a difficult point when writing in L2 ("I usually mistake the genders. They differ in Albanian and I am confused when I am in a hurry to finish my writing. I have improved myself in the articles, though!"- pupil 5)

The quantitative analysis indicated that bilingual pupils face greater difficulties in selecting appropriate, matching vocabulary $(32,6 \%)$, spelling words $(30,6 \%)$ and the overall planning of the content of their writings $(25,6 \%)$ (see table 10).

The differentiations uncovered by the independence tests ( $\chi^{2}$ and Monte Carlo) regarding both writing competence level and type of bilingualism indicated significant correlations with the difficulties encountered in creative writing (see table 11). 
Table 10.

Descriptive indices of difficulties on while-writing phase

\begin{tabular}{|l|l|l|l|l|}
\hline Categories & Codes & Low & Fair & High \\
\hline \multirow{3}{*}{ Word level } & USAPVOC & $37,2 \%$ & $30,2 \%$ & $32,6 \%$ \\
\cline { 2 - 5 } & CORSP & $37,2 \%$ & $32,6 \%$ & $30,2 \%$ \\
\hline \multirow{4}{*}{ Text level } & GENID & $27,9 \%$ & $51,2 \%$ & $20,9 \%$ \\
\cline { 2 - 5 } & ORGID & $25,6 \%$ & $51,2 \%$ & $23,3 \%$ \\
\cline { 2 - 5 } & CONPLA & $16,3 \%$ & $58,1 \%$ & $25,6 \%$ \\
\cline { 2 - 5 } & SYNTX & $67,4 \%$ & $27,9 \%$ & $4,7 \%$ \\
\cline { 2 - 5 } & CORGRAMM & $46,5 \%$ & $41,9 \%$ & $11,6 \%$ \\
\hline
\end{tabular}

Table 11.

Differences between good-weak writers and successive-simultaneous bilinguals in cognitive and metacognitive strategies use

\begin{tabular}{|c|c|c|c|}
\hline Categories & Codes & Weak-Good writers & Successive-Simultaneous bilinguals \\
\hline \multirow{2}{*}{ Word level } & USAPVOC & $\begin{array}{l}\chi^{2}=20,930, d f=2, p=0,000 \\
\text { Cramer's V=0,698 }\end{array}$ & $\begin{array}{l}\chi^{2}=6,503, d f=2, p=0,039 \\
\text { Cramer's V=0,389 }\end{array}$ \\
\hline & CORSP & $\begin{array}{l}\chi^{2}=19,523, d f=2, p=0,000 \\
\text { Cramer's V=0,674 }\end{array}$ & $\begin{array}{l}\chi^{2}=6,088, d f=2, p=0,048 \\
\text { Cramer's V }=0,376\end{array}$ \\
\hline \multirow{5}{*}{$\begin{array}{l}\text { Text } \\
\text { level }\end{array}$} & \multirow{2}{*}{ GENID } & $\chi^{2}=10,942, d f=2, p=0,004$ & \\
\hline & & Cramer's V $=0,504$ & \\
\hline & GENID & $\begin{array}{l}\chi^{2}=11,674, \mathrm{df}=2, \mathrm{p}=0,003 \\
\text { Cramer's V=0,521 }\end{array}$ & \\
\hline & CONPLA & $\begin{array}{l}\chi^{2}=14,388, d f=2, p=0,001 \\
\text { Cramer's V=0,578 }\end{array}$ & \\
\hline & CORGRAMM & $\begin{array}{l}\chi^{2}=11,983, d f=2, p=0,002 \\
\text { Cramer's V=0,528 }\end{array}$ & \\
\hline
\end{tabular}

\section{Concluding Remarks}

The results of the research demonstrate that bilingual pupils employed a wide range of cognitive writing strategies, such as retrieving, rereading, avoidance, elaborating and translating. Many metacognitive strategies were also employed through all stages, like monitoring, planning, rehearsing, error correction, evaluating and seeking for feedback. Regarding the volume of strategies recorded, the most 'strategy generating' stage was accented to be the while-writing one.

The findings highlighted some remarkable differences regarding the two levels of L2 language proficiency and types of bilingualism (simultaneous-successive). 
The less skilled writers made use of limited strategies and dealt with greater difficulties. Furthermore, they showed lower competence in the macro-processes of writing, narrow metacognitive awareness and metacognitive strategy use, in contrast to the good writers who were more efficient in their strategy use. The findings are in line with earlier research (Silva \& Brice 2004; Ehrman et al. 2003), that have confirmed that good writers are more effective than their weaker counterparts in researching and generating ideas, hypothesizing. Moreover, the weak writers differ significantly regarding their use of metacognitive strategies, such as global planning, evaluating ideas and rehearsing ideas before writing (Ferrari et. al. 1998; Griva et al. 2009). The weak writers faced greater difficulties in the lexical level, like selecting the appropriate vocabulary and spelling, in contrast to the good writers, who focused on the macro process of writing demonstrating less difficulty in production and organization of ideas.

In reference to the use of strategies by the simultaneous and successive bilinguals, no significant differentiations were indicated regarding the prewriting and post-writing strategies. Some noteworthy statistical differentiations were observed between the pupils of two types of bilingualism at the whilewriting stage. Simultaneous bilinguals were proved more efficient in choosing effective cognitive strategies, such as making connections, recalling and the metacognitive strategy of self-correcting. In reverse, successive bilinguals turned to translating. Previous research confirms this result as skilled writers and writers with higher L2 proficiency are less likely to use L1 while writing in L2 than the weaker ones (Victori 1999; Sasaki 2002; Lee 2003; Sousa et al. 2011).

In addition, successive bilinguals dealt with extensive difficulties, in selecting proper vocabulary as well as spelling. 


\section{References}

Akita, K., Prakash P., Prathibha, B., Panah, M.A. and Rao, C. 2007. Drawing and Emergent Writing in Young Children. Psychological Studies 52: 216-222.

Baroudy, I. 2008. Process writing: successful and unsuccessful writers. International Journal of English Studies 8(2): 43-63.

Bazerman, C. 2008. Handbook of research on writing: history, society, school, individual, text. New York: Taylor and Francis.

Berman, R. 1994. Learner's transfer of writing skills between languages. TESL Canada Journal 12(1): 29-46.

Carson, J. and Longhini, A. 2002. Focusing on learning styles and strategies: A diary study in an immersion setting. Language Learning (52)2: 401-438.

Chamot, A.-U. 2004. Issues in language learning strategy research and teaching. Electronic Journal of Foreign Language Teaching 1(1): 14-26.

De Larios, J.R., Manchon, R. and Murphy, L. 2006. Generating text in native and foreign language writing: a temporal analysis of problem-solving formulation processes. The Modern Language Journal 90: 100-114.

Ehrman, M., Leaver, B.L. and Oxford, R. 2003. A brief overview of individual differences in second language learning. System 31: 313-330.

Ferrari, M., Bouffard, T. and Rainville, L. 1998. What makes a good writer? Differences in good and poor writers' self-regulation of writing. Instructional Science 26(6): 473-488. 
Graham, S. and Harris, K. 1994. The role and development of self-regulation in the writing process. In D. Schunk and B. Zimmerman (Eds.), Self-regulation of learning and performance: Issues and educational applications. New York: Lawrence Erlbaum, 203-228.

Green, J. and Rebecca, Oxford. 1995. A closer look at learning strategies, L2 proficiency, and gender. TESOL Quarterly 29(2): 261-297.

Griva, E., Tsakiridou, E. and Nihoritou, I. 2009. Study of FL composing process and writing strategies employed by young learners. In M. Nikolov (Ed), Early Learning of Modern Foreign Languages. Bristol: Multilingual Matters, 132-148.

Hsiao, T.Y. and Oxford, R. 2002. Comparing theories of language learning strategies: A confirmatory factor analysis. Modern Language Journal 86(3): 368383.

Khalil, A. 2005. Assessment of Language Learning Strategies Used by Palestinian EFL Learners. Foreign Language Annals 38: 108-117.

Lan, R. and Oxford, R. 2003. Language learning strategy profiles of elementary school students in Taiwan. IRAL 41: 339-379.

Lantolf, J.P. 2004. Sociocultural theory and second language learning. Oxford: Oxford University Press.

Lee, S. 2003. ESL learners' vocabulary use in writing and the effects of explicit vocabulary instruction. System 31: 537-561.

Miles, M. and Huberman, M. 1994. Qualitative Data Analysis. Thousand Oaks, CA: Sage Publications.

Nyikos, M. and Oxford, R. 1993. A factor analytic study of language learning strategy use: Interpretations from information processing theory and social psychology. Modern Language Journal 77(1): 11-22.

Olivares-Cuhat, G. 2002. Learning Strategies, Writing Textbooks and Achievement in the Spanish Classroom: A Case-Study. Foreign Language Annals 35(5): 561570.

O'Malley, M. and Chamot, A.-U. 1990. Learning strategies in second language acquisition. Cambridge, England: Cambridge University Press. 
Oxford, R. 1990. Language learning strategies: What every teacher should know. Boston: Heinle and Heinle.

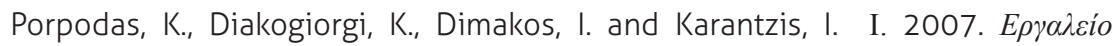

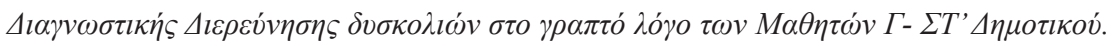
Athens: Greek Ministry of National Education and Religious Affairs - EPEAEK (2).

Riazi, A. 1997. Acquiring disciplinary literacy: A social-cognitive analysis of text production and learning among Iranian graduate students of education. Journal of Second Language Writing 6(2): 105-137.

Sasaki, M. 2000. Toward an empirical model of EFL writing processes: An exploratory study. Journal of Second Language Writing 9(3): 259-291.

Sasaki, M. 2002. Building an empirically-based model of EFL learners' writing processes. In G. Rijlaarsdam, S. Ransedell and M. Barbier (Eds.), Studies in Writing. Netherlands: Kluwer Academic Publishers, 49-80.

Silva, T. and Brice, C. 2004. Research in teaching writing. Annual Review of Applied Linguistics 24: 70-106.

Sousa, D., Greenop, K. and Fry, J. 2011. Cross-language transfer of spelling strategies in English and Afrikaans Grade 3 children. International Journal of Bilingual Education and Bilingualism 14(1): 49-67.

Vicrori, B. 1999. An analysis of writing knowledge in EFL composing: a case study of two effective and two less effective writers. System 27(4): 537-555.

Wenden, A. 1991. Learner Strategies in Language Learning. Englewood Cliffs, N]: Prentice Hall. 
Major Trends in Theoretical and Applied Linguistics 